\title{
Activities of living of disabled people according to the Roper-Logan- Tierney model of nursing
}

\author{
Atividade de vida de pessoas com deficiência segundo modelo de enfermagem de Roper- \\ Logan-Tierney
}

\section{Actividad de vida de personas con discapacidad según el modelo de enfermería de Roper- Logan-Tierney}

Gisele Nogueira de Moura ${ }^{1}$, Jennara Candido do Nascimento ${ }^{2}$, Maria Alzete de Lima ${ }^{3}$, Natasha Marques Frota ${ }^{2}$, Vicente Matias Cristino ${ }^{2}$, Joselany Afio Caetano ${ }^{4}$

Objective: to identify the activities of living of disabled people by applying the Roper-Logan-Tierney Model of Nursing. Methods: cross-sectional study conducted in private university. The population comprised 13 people with physical and sensory disabilities, who practiced water sports. Data collection occurred through structured script. Results: most participants came from the capital, were male, aged between 19 and 69 years. The most affected activities of living were Maintaining a safe environment, Mobilization, and Sleeping. There were 15 nursing diagnoses related to each activity identified, in addition to the expected outcomes and interventions. Conclusion: the model of living enabled to identify the group's limitations in carrying out activities of living, constituting a fertile field for nursing actions.

Descriptors: Nursing Diagnosis; Models, Nursing; Disabled Persons.

Objetivo: identificar as atividades de vida diária de pessoas com deficiência, por meio da aplicação do Modelo de Enfermagem de Roper-Logan-Tierney. Métodos: pesquisa transversal, realizada em universidade privada. Participaram 13 pessoas com deficiência física e sensorial, que praticavam atividades aquáticas. Os dados foram coletados através de roteiro estruturado. Resultados: a maioria dos participantes era procedente da capital, do sexo masculino, com faixa etária entre 19 e 69 anos. As atividades de vida mais afetadas foram: manter ambiente seguro, mobilizar-se e dormir. Para cada atividade identificada, foram relacionados 15 diagnósticos de enfermagem, além dos resultados esperados e intervenções. Conclusão: o modelo de vida permitiu a identificação das limitações do grupo para a realização das atividades de vida, o que representa um campo fértil para as ações de enfermagem.

Descritores: Diagnóstico de Enfermagem; Modelos de Enfermagem; Pessoas com Deficiência.

Objetivo: identificar las actividades diarias de personas con discapacidad mediante aplicación del Modelo de Enfermería de Roper-Logan-Tierney. Métodos: estudio transversal, realizado en universidad privada. Participaron 13 personas con discapacidades físicas y sensoriales, que practicaban actividades acuáticas. Datos recolectados a través de guion estructurado. Resultados: mayoría de los participantes provenían de la capital, sexo masculino, con edades comprendidas entre 19 y 69 años. Las actividades de vida más afectadas fueron: mantener el ambiente seguro, movilizarse y dormir. Para cada actividad identificada, fueron relacionados 15 diagnósticos de enfermería, además de los resultados y las intervenciones previstas. Conclusión: el modelo de vida permitió la identificación de las limitaciones del grupo para llevar a cabo actividades de vida, lo que representa campo fértil para las acciones de enfermería.

Descriptores: Diagnóstico de Enfermería; Modelos de Enfermería; Personas com Discapacidad.

\footnotetext{
${ }^{1}$ Secretaria de Saúde do Município de Itaitinga. Itaitinga, CE, Brazil.

${ }^{2}$ Centro Universitário Estácio do Ceará. Fortaleza, CE, Brazil.

${ }^{3}$ Universidade Federal do Rio Grande do Norte. Natal, RN, Brazil.

${ }^{4}$ Universidade Federal do Ceará. Fortaleza, CE, Brazil.
}

Corresponding author: Joselany Áfio Caetano

Rua Aécio Cabral, 300 Casa 400 Cocó. CEP: 60135480 - Fortaleza, CE, Brazil. E-mail: joselany@ufc.br 


\section{Introduction}

Disabilities are problems in body function or structure, caused by abnormality, defect, loss, or other significant change from what is usually considered the normal biomedical state (standard) of body and functions. They can be temporary or permanent, progressive, regressive or stable, intermittent or continuous. They can be part of or express health condition, but do not necessarily indicate the presence of disease or that the individual should be considered ill(1).

Data from 2010 Demographic Census reveal that $45,606,048$ people, $23.9 \%$ of the Brazilian population, claimed to have some kind of impairment, whether visual, auditory, motor, or mental. Most of these people live in urban areas, with special reference to the Northeast region, presenting the largest number of municipalities where people live with at least one type of disability ${ }^{(2)}$.

Some difficulties may be present in the daily lives of disabled persons, compromising the performance of activities of living, as well as social integration. In both cases, an intervention is possible, aimed at improving the quality of life of this population. In this context, nurses can help disabled people to develop skills that allow them to perform activities of living safely, through the systematization of care, evaluating not only the physical and biological factors, but also the environmental and socio-cultural aspects.

Given the above, in order to promote efficient and quality care, the nursing team should use the Nursing Process, which consists of five interrelated steps: assessment, diagnosis, planning, implementation, and evaluation, offering an organized and systematic way of thinking about nursing $\operatorname{care}^{(3)}$. The Process intends to develop nursing care based on the needs of individuals and groups on their care. This process summarizes the interventions to be provided and allows nurses to meet the deficits presented by these patients, as well as difficulties, facilities, doubts, and anxieties.

Therefore, the activities of living model ${ }^{(4)}$ proposed by Roper-Logan-Tierney is an essential instrument for implementing the nursing process.
Based on this model, nurses identify the activities of living that may be compromised, to then develop care plans seeking to promote health and well-being.

Literature reveals studies involving disabled persons, the scope, however, focuses on actions for rehabilitation and social inclusion ${ }^{(5-6)}$. Nevertheless, there are few studies describing how nursing interventions can be performed, from theidentification of nursing diagnoses, based on the activities of living performed by each individual. Developing research that investigate the activities of living of disabled people becomes essential for creating subsidies that help nurses to develop care based on the difficulties experienced by each individual, helping in fighting the disease or its consequences, such as disabilities.

In this perspective, the following questions arose: What are the most affected activities of living among disabled persons? What are the most frequent nursing diagnoses in this population?

Thus, this study aimed to identify the activities of daily living of disabled people by applying the Roper-Logan-Tierney Model of Nursing, and describe the Systematization of Nursing Care using the Taxonomy I of NANDA's nursing diagnoses ${ }^{(7)}$, the Nursing Interventions Classification (NIC), and the Nursing Outcomes Classification (NOC).

Attempting to meet the needs of each participant, this study used the Roper-Logan-Tierney model of nursing, in order to identify the main characteristics of living, their significance, and the interrelationships between theirs components. We focused on a set of 12 activities of living: maintaining a safe environment, communication, breathing, eating and drinking, elimination, washing and dressing, controlling temperature, mobilization, working and playing, expressing sexuality, sleeping, and death and dying. These activities are closely related to each other and are influenced by biological, psychological, environmental, socio-cultural, and politico-economic factors $^{(4)}$.

Using this model becomes relevant, since people perform a number of important activities for maintaining health and well-being. These same activities are closely related, common in the daily 
lives of individuals, as part of living. For developing the activities of living in the various stages of life, one has a continuum ranging from total dependence to complete independence, possibly presenting differences in performing some activity.

The abovementioned model includes the phases of the assistance methodology itself, namely: assessing the activities of living, planning nursing care, choosing the interventions to implement, and subsequent evaluation. Therefore, during nursing consultation, in addition to the survey relating to personal, health, and family data, it also includes the "Evaluation of Activities of Living." After data analysis, the problems are identified and written in the form of nursing diagnoses. Later, comes the development of the nursing care planning, which requires continuous review of data collected from the initial assessment. Then, the disabled person establishes the goals to achieve.

In the "Nursing intervention" phase, nurses select and perform the nursing actions, aimed at preventing problems, promoting physical and psychological comfort, and reducing dependency, making them able to seek help to meet the responsibility for self-care. Nonetheless, nursing interventions should focus on the routines of disabled people, aiming to minimize the problems related to activities of living. For the last phase, identified as "Assessment of assistance provided", the criterion used is the performance of disabled persons in every activity for achieving the goals previously set.

\section{Method}

Descriptive cross-sectional research conducted at the campus of a private higher education institution, located in Fortaleza-CE, Brazil, which had a modern sports park in accordance with the standards of Brazilian and even international confederations for every sport, serving as a sports hub to the academic community as well as civil society, particularly to disabled people.

The study comprised 13 people with physical and sensory disabilities who were engaged in water sports offered at that institution, selected according to the following criteria: 18 years or older, regardless of gender, education, marital status, and origin. For entering in this study, those newly admitted to the group and who presented cognitive limitations preventing from responding coherently to interview questions were not considered.

Data collection occurred from September 2010 to February 2011, through an instrument in form of a structured interview based on the Roper-LoganTierney conceptual model ${ }^{(4)}$, consisting of two parts. The first aimed to identify the participants (name, age, gender, marital status, and cause of disability). While the second was based on the 12 Activities of Living proposed by the model: (1) maintaining a safe environment; (2) communication; (3) breathing; (4) eating and drinking; (5) elimination; (6) washing and dressing; (7) controlling temperature; (8) mobilization; (9) working and playing; (10) expressing sexuality; (11) sleeping; and (12) death and dying.

The interviews took place individually in between the activities developed at the pool. At first, they were invited to participate in the study, as well as informed of the research objectives. After acceptance, participants are conducted to a previously scheduled place for data collection.

It is worth highlighting that this study did not aim to evaluate the participants' level of dependence/ independence. This way, they described the activities of living based on real or potential problems reported by each individual. Nursing diagnoses related to each activity of living registered were identified, according to NANDA-I Taxonomy ${ }^{(7)}$. Furthermore, the expected results were described (NOC), as well as the main interventions (NIC) required for each problem/ diagnosis related to the activities of living.

Results were organized in figure and the analysis was based on the Roper-Logan-Tierney model and pertinent literature. The study took place grounded on the ethical principles of Resolution $466 / 2012$ of the National Health Council, approved by the Research Ethics Committee of the institution under protocol No. 028/2010. 


\section{Results}

Most participants were male, aged between 19 and 69 years, and from Fortaleza. Regarding marital status, six were married, six single, and one separated. As for the cause of disability, ten were the acquired type and three congenital, such as retinitis pigmentosa. Among the disabilities acquired, we highlight the following causative events: stroke (3), motorcycle accident (3), work accident (1), fall (1), gunfire (1), and anaphylactic shock (1).

Figure 1 shows the distribution of diagnoses, expected outcomes, and nursing interventions identified from the activities of living, according to reports of the study participants.

\begin{tabular}{|c|c|c|c|}
\hline $\begin{array}{l}\text { Activities of } \\
\text { living }\end{array}$ & Nursing Diagnosis & NOC & NIC \\
\hline \multirow{2}{*}{$\begin{array}{l}\text { Maintaining a } \\
\text { safe environment }\end{array}$} & Risk for falls (00155) (2000) & $\begin{array}{l}\text { Fall prevention behavior (1909) } \\
\text { Ambulation: wheelchair (0201) }\end{array}$ & $\begin{array}{l}\text { Environmental management: safety (64865) } \\
\text { Fall prevention (6490) }\end{array}$ \\
\hline & \begin{tabular}{|l}
$\begin{array}{l}\text { Readiness for enhanced self-health } \\
\text { management }(00162)\end{array}$ \\
\end{tabular} & $\begin{array}{l}\text { Risk control (1902) } \\
\text { Adherence behavior (1600) } \\
\end{array}$ & $\begin{array}{l}\text { Risk identification (6610) } \\
\text { Health education (5510) } \\
\end{array}$ \\
\hline \multirow{2}{*}{ Communication } & $\begin{array}{l}\text { Risk for loneliness (00054) }(1994,2006 \text {, } \\
\text { NE 2.1) }\end{array}$ & Social involvement (1503) & $\begin{array}{l}\text { Socialization enhancement (5110) } \\
\text { Visitation facilitation (7586) } \\
\text { Support system enhancement (5440) } \\
\end{array}$ \\
\hline & $\begin{array}{l}\text { Impaired verbal communication (00051) } \\
(1983,1996,1998)\end{array}$ & $\begin{array}{l}\text { Communication: expressive } \\
(0903)\end{array}$ & \begin{tabular}{|l} 
Communication enhancement: speech deficit \\
(4976) \\
Anxiety reduction (5820) \\
\end{tabular} \\
\hline $\begin{array}{c}\text { Eating and } \\
\text { drinking }\end{array}$ & Disturbed personal identity (00121) & Health orientation (1705) & \begin{tabular}{|l} 
Self-esteem enhancement (5400) \\
Body image enhancement (5220) \\
\end{tabular} \\
\hline \multirow{2}{*}{ Elimination } & Reflex urinary incontinence (00018) & Urinary continence (0502) & $\begin{array}{l}\text { Urinary catheterization: intermittent (0582) } \\
\text { Urinary incontinence care (0610) } \\
\text { Tube care: urinary (1876) }\end{array}$ \\
\hline & Risk for constipation (00015) & Bowel elimination (0551) & $\begin{array}{l}\text { Nutritional counseling (5246) } \\
\text { Medication management }(2380) \\
\text { Nutrition management }(1100) \\
\end{array}$ \\
\hline \multirow[t]{2}{*}{$\begin{array}{l}\text { Washing and } \\
\text { dressing }\end{array}$} & Bathing self-care deficit (00108) & $\begin{array}{l}\text { Self-care: bathing (0301) } \\
\text { Self-care: oral hygiene (0308) }\end{array}$ & \begin{tabular}{|l} 
Bathing $(1610)$ \\
Nail care $(1680)$ \\
Hair care $(1670)$ \\
Foot care $(1660)$ \\
Oral health maintenance $(1710)$ \\
Self-care assistance: bathing/hygiene (1801) \\
\end{tabular} \\
\hline & Dressing self-care deficit (00109) & Self-care: dressing (0302) & $\begin{array}{l}\text { Dressing (1630) } \\
\text { Self-care assistance: dressing/grooming (1802) }\end{array}$ \\
\hline \multirow{2}{*}{ Mobilization } & Impaired wheelchair mobility (00089) & $\begin{array}{l}\text { Ambulation: wheelchair (0201) } \\
\text { Coordinated movement (0212) }\end{array}$ & $\begin{array}{l}\text { Positioning: wheelchair (0846) } \\
\text { Environmental management: safety (6486) } \\
\end{array}$ \\
\hline & Chronic pain (000132) & Pain control (1605) & $\begin{array}{l}\text { Heat/cold application (1380) } \\
\text { Pain management (1400) }\end{array}$ \\
\hline \multirow{2}{*}{$\begin{array}{l}\text { Working and } \\
\text { playing }\end{array}$} & Deficient diversional activity (00097) & $\begin{array}{l}\text { Social involvement (1503) } \\
\text { Leisure participation (1604) }\end{array}$ & $\begin{array}{l}\text { Socialization enhancement (5100) } \\
\text { Family mobilization (7120) }\end{array}$ \\
\hline & Impaired social interaction (00052) & \begin{tabular}{|l|} 
Family social climate (2601) \\
Social involvement (1503) \\
\end{tabular} & Socialization enhancement (5100) \\
\hline $\begin{array}{l}\text { Expressing } \\
\text { sexuality }\end{array}$ & Ineffective sexuality pattern (00065) & \begin{tabular}{|l|} 
Sexual identity (1207) \\
Self-esteem (1205) \\
Role performance (1501) \\
\end{tabular} & $\begin{array}{l}\text { Self-esteem enhancement (5400) } \\
\text { Coping enhancement (5230) } \\
\text { Sexual counseling (5248) } \\
\end{array}$ \\
\hline Sleeping & Disturbed sleep pattern (00198) & Sleep (0004) & \begin{tabular}{|l} 
Positioning (0840) \\
Medication management (2380) \\
Urinary Iincontinence care: enuresis (0612) \\
Environmental management: comfort (6482) \\
\end{tabular} \\
\hline
\end{tabular}

Figure 1 - Distribution of nursing diagnoses, interventions, and expected outcomes identified for each activity of living affected 
From the evaluation, among the twelve activities of living proposed ${ }^{(4)}$, participants reported difficulties during the implementation of nine, and the most mentioned were: maintaining a safe environment, mobilization, and sleeping. According to participants' statements, the following activities of living were not changed in their daily lives: controlling temperature, breathing, and death and dying.

Nursing diagnoses, expected outcomes (NOC), and interventions (NIC) were associated with each activity identified. Thus, we obtained 15 nursing diagnoses, of which the most common were: Risk for falls and Disturbed sleep pattern, both identified in six (46\%) participants, in addition to Impaired wheelchair mobility, present in three (23\%) participants.

\section{Discussion}

Intertwining of activities of living and nursing diagnoses enable better approach of professionals towards disabled persons, as it allows knowing details that might compromise self-care actions and consequently the quality of life. Based on the identified diagnoses, it is possible to create valuable information for decision-making and development of a treatment plan focused on the real needs and potentials of disabled people.

To perform the activities of living, disabled individuals must adopt measures to prevent accidents in the various life scenarios, such as work and leisure. Maintaining a safe environment involves actions aimed at helping people identify risk situations, thus minimizing the possibility of events that expose them to physical damages, like falls.

Falls represent a public health problem, being the most common cause of nonfatal lesions and hospital admissions for traumatic injuries, as well as loss of independence ${ }^{(5)}$. Susceptibility to fall was present in 12 (25\%) participants due to the presence of acquired sequelae resulting from several injuries, limiting their mobility at home and in public spaces. Among the consequences observed, the most frequent were associated with stroke, motorcycle accident, and congenital malformation, especially atrophy, amputations, and gait disorders. Regardless of cause, participants were using some mobility assistive device, such as cane, crutches, wheelchairs, and prosthetics.

With regard to nursing diagnoses, Risk for falls and Readiness for enhanced self-health management were highlighted for the activity of living. Undoubtedly, there is need to assess factors that may predispose individuals to falls and thereby minimize possible complications, such as severe fractures. Lack of infrastructure of public spaces for leisure and circulation, as well as the inappropriate use of mobility assistive devices, represents risk for the physical integrity of disabled persons.

Regarding the Communication activity, we focused on observations related to how participants used verbal language (writing and speaking), in addition to non-verbal aspects (body and facial expressions). In some reports, it was possible to observe significant changes in the communication that participants established with family and friends. Some difficulties occurred due to the sequelae arising from certain diseases, like stroke, in which the person showed difficulty in articulating words, impairing speech. Nevertheless, some participants presented non-physical limitations, rather related to feelings such as shame, fear, and anxiety. Therefore, the main nursing diagnoses evidenced for this activity were Impaired verbal communication and Risk for loneliness.

It is worth highlighting that the care and interaction process with disabled persons transcends words and affects directly and deeply the effectiveness 
of nursing $\operatorname{care}^{(8)}$. Some techniques may be effective to improve communication, like using short sentences and simple words, in addition to follow up with speech therapists and psychologists in cases where emotional factors hinder the openness to dialogue with another. Nurses must supervise those measures, as well evaluate them with the target audience of interventions, checking if the measures adopted are generating benefits or there is need to look for other means to get results that are more satisfactory.

Faced with the changes generated by the loss of a limb, or the limitations imposed by the presence of sequelae, the daily lives of those people may be affected, especially concerning the activities of eating and drinking. For most individuals, these two activities take place without much difficulty, however, in the presence of some disability, a careful evaluation of that activity of living is required. For this, we added the diagnosis Disturbed personal identity.

We observed that the participants were worried about the increase in body weight, but this concerned the aesthetics and not the maintenance of healthy eating habits. Nutritional care for disabled people should be redoubled, since they are more likely to experience osteoporosis, kidney stones, altered metabolism of carbohydrates, proteins and lipids. Moreover, they have higher probability of developing cardiovascular diseases.

Regarding the activity Elimination, it includes investigating the actions performed by individuals for bladder emptying, intestinal, the use of drugs at the time, and physical motor skills used to maintain these habits ${ }^{(9-10)}$. Additionally to these aspects, it is also crucial to verify the knowledge of disabled individuals about bladder catheterization techniques, signs and symptoms suggestive of urinary tract infection, and constipation treatments. Furthermore, it seems relevant to clarify doubts about this procedure. The main nursing diagnoses identified for this activity were Reflex urinary incontinence and Risk for constipation.

We also identified that participants had difficulties to perform the activity of living Washing and dressing. Conducting actions like brushing your teeth, shaving, and showering was challenging for this group of people. For this reason, it is imperative to redouble hygiene care, stimulating disabled persons to use assistive devices, such as gloves and long handled sponges, besides recommending the inclusion of the spouse, or relative, as support for carrying out activities more complex, or that involve more elaborate movements, thereby ensuring proper and safe performance of self-care actions. The diagnoses Bathing self-care deficit and Dressing self-care deficit were considered consistent with this activity.

The activity Mobilization was also altered among study participants. For this activity, we identified two nursing diagnoses: Impaired wheelchair mobility and Chronic pain. The existence of difficulties regarding the use of the wheelchair and hygienic chair, and the transfer from chair to bed and other surfaces, was present among the three wheelchair respondents. It was also possible to observe difficulties to move through streets and avenues among other study participants, since the infrastructure of cities still does not meet the peculiarities of disabled people. Mobility limitations result from physiological changes and preexisting chronic conditions that negatively affect their quality of life ${ }^{(11)}$.

Maintaining a safe environment involves offering effective architectural structure, the appropriate use of mobility assistive devices, and properly recognizing and managing the acquired sequelae. In this context, they are utterly important to the adoption of preventive care. It is essential to bear in mind that impaired mobility is related to both 
individual factors and infrastructure problems in the environments where we live, whose traffic lights have no beep, sidewalks have large gaps, and the public transport system does not meet the specific needs of disabled people ${ }^{(12)}$. Thus, nurses are responsible for developing educational actions aimed at addressing the problems that affect disabled persons, helping them to overcome constraints seeking better health outcomes.

In addition to mobility problems, some participants reported experiencing changes in the activity Working and playing. Many were retired or on leave during the survey period and did not often have leisure and fun moments. Selected diagnostics to characterize this activity of living were Deficient diversional activity and Impaired social interaction.

Even today, there is a strong association between disability and negative, derogatory meanings, or feelings of inadequacy, resulting in the social devaluation of disabled people ${ }^{(13)}$. That said, it is a challenge to ensure people with physical or sensory disabilities social relationships without loss, since misconducts prevail in the context of disability, in addition to the perpetuation of feelings such as pity, shame, and fear.

Generalizations brought by stereotypes about the inability of disabled persons may hinder their integration into the labor market and their professional development ${ }^{(14)}$. Survey conducted revealed that to gain access to the labor market, disabled people use political influence or intermediation from friends and family in order to ensure the fundamental right of citizens to work ${ }^{(13)}$.

Given the above, disabled individuals must be perceived according to their potentials and needs, not just from the function deviation or loss that their body structure determines. Society tends to associate the body with some physical impairment to disability, which has translated ways of social representation that stereotype and segregate disabled people ${ }^{(15)}$.

Inclusive situations focused on Culture, Education, Leisure and other social sectors, considering the diversity of the human condition, tend to reduce the effects of discriminatory, biased situations in social life that exclude anyone with or without disabilities ${ }^{(16)}$. This way, sports enter this context as an instrument for integrating the individual to society. Sports practice contributes to the socialization of disabled people as it facilitates communication, personal fulfillment, self-image, selfconcept, and autonomy ${ }^{(17)}$. Sports, physical activities, and recreation are important factors, since they are vital to the population health and well-being ${ }^{(18)}$.

Among the modalities of physical activity available, one in particular offers more advantages to disabled persons, namely water activities. Through these, individuals have the opportunity to experience sensations and movements, which often they cannot perform given the physical limitation, or social and environmental barriers ${ }^{(19)}$. Swimming brings benefits to disabled people, especially in relation to the motor aspects, contributing to maintaining posture, trunk stabilization, and body awareness ${ }^{(20)}$.

Given the above, study participants were unanimous in recognizing that after starting pool activities, there was an improvement in overall health, besides feeling more confident and less dependent. For non-sighted individuals, swimming promotes their development and helps to improve the body and kinesthetic knowledge, making them more comfortable to discover and explore their body ${ }^{(21)}$.

Positive feelings concerning themselves are important to allow disabled people to experience sexuality, which at times can be hidden, causing painful processes and compromising affectional bonding. The activity of living Expressing sexuality was altered in 
some participants. The main nursing diagnosis related was Ineffective sexuality pattern.

Despite the progress regarding the real potential and needs of disabled individuals, prejudiced ideas about their sexuality still prevail in the speeches of laypersons, family, and community, as if it were always atypical or unhappy. These generalizations are based on stereotypes grounded by erroneous beliefs that put disabled people as someone incapable and limited ${ }^{(22)}$. Many experienced discomfort and disappointment when trying to reestablish past relationships, or during new attempts, creating barriers. Some did not have an active sex life for several years, due to feelings such as shame, fear, and anger. Few were comfortable to express real yearnings to the partner, besides not seeking professional counseling.

Regarding the activity Sleeping, we observed that the factors that most compromised this activity were the periodic changes in supine position, quality of mattress and pillows used, medications used, and urinary incontinence. Lack of adequate sleep can decompensate the individual, exposing them to the occurrence of diseases such as depression and anxiety. Biological, psychological, and environmental aspects influence this activity of living. The diagnosis elected to this activity was Disturbed sleep pattern. For these reasons, nurses are accountable for developing care plans involving these three influential elements, offering viable solutions to improve sleep and wakefulness period of disabled people.

For this purpose, the survey of specific data related to activities of living is imperative for the development of nursing actions aimed at disabled persons in everyday life. These actions should help people in performing the activities, guaranteeing them safety and greater autonomy for self-care.

\section{Final Considerations}

We conclude that the model of living enabled to identify the group's limitations in performing activities of living, which represents a fertile field for nursing actions. The results were enlightening and signaled there is still much to do for people with physical, intellectual, or sensory impairments. Adopting the Model of Living allowed to determine the main changes in the daily lives of these people, promoting the election of appropriate forms of care to each situation.

Participants needed unique care plans, addressing not only physical, but also subjective aspects, articulating family and community in search of practices more effective that assist in the self-care development. Therefore, nurses must work together to develop the potential of individuals through critical-reflective attitude, using various resources, such as the nursing consultation, offering a channel for discussion between professionals and individuals.

The inclusion of spouses and family is necessary in developing care plans to disabled individuals, making the process more dynamic, favoring rehabilitation and strengthening affective bonds, very needed during the development of proposed activities.

Using the Activities of Living Model is utterly important for professional performance, since it allows to identify needs, health problems, contextualized and individually. Thus, the real and potential needs are met more efficiently based on a more detailed evaluation.

As limitation for this study, we highlight the small group approach, and the fact it was not a thorough research about the degree of dependence/ independence of the participants and its impact on daily lives of disabled people. There is need for further studies on the subject, seeking to improve the quality of lives of these people, looking for ways that favor their life in society. 


\section{Collaborations}

Moura GN contributed to data collection, organization, analysis, and interpretation, and drafting of the article. Nascimento JC participated in the construction of the project, data collection, organization, analysis, and interpretation, and drafting of the article. Lima MA, Frota NM and Cristino VM contributed to the construction of the article. Caetano JA contributed to data analysis and interpretation, drafting of the article, and final approval of the version to be published.

\section{References}

1. World Health Organization. Classificação internacional de funcionalidade, incapacidade e saúde. Lisboa: World Health Organization; 2004.

2. Instituto Brasileiro de Geografia e Estatística (IBGE). Censo demográfico 2010: características gerais da população, religião e pessoas com deficiência. Rio de Janeiro: IBGE; 2010.

3. Alfaro-Lefevre R. Aplicação do processo de enfermagem uma ferramenta para o pensamento crítico. 7aㅡ ed. Porto Alegre: Artmed; 2010.

4. Roper N, Logan WW, Tierney AJ. Modelo de enfermagem. 3aㅡ ed. Lisboa: McGraw-Hill; 1995.

5. Finlayson ML, Peterson EW. Falls, aging, and disability. Phys Med Rehabil Clin N Am. 2010; 21(2):357-3.

6. Carvalho-Freitas MN, Toledo ID, Nepomuceno MF, Suzano JCC, Almeida LAD. Socialização organizacional de pessoas com deficiência. Rev Adm Empres. 2010; 50(3):264-75.

7. Nanda Internacional. Diagnósticos de Enfermagem da Nanda: definições e classificação 2012-2014. Porto Alegre: Artmed; 2013.

8. Rebouças CBA, Cezario KG, Oliveira PMP, Pagliuca LMF. People with physical and sensory deficits: perceptions of undergraduate nursing students. Acta Paul Enferm. 2011; 24(1):80-6.
9. Andrade LT, Araújo EG, Andrade KRP, Soares DM, Chianca TCM. Role of nursing in physical rehabilitation. Rev Bras Enferm. 2010; 63(6):1056-60.

10. Assis GM, Faro ACM. Clean intermittent self catheterization in spinal cord injury. Rev Esc Enferm USP. 2011; 45(1):289-93.

11. Paula MP, Sawada NO, Nicolussi AC, Andrade CTAE, Andrade V. Quality of life of elderly people with impaired physical mobility. Rev Rene. 2013; 14(6):1224-31.

12. Souza EL, Moura GN, Nascimento JC, Lima MA, Pagliuca LM, Caetano JA. Diagnósticos de enfermagem embasados na Teoria do autocuidado em pessoas com deficiência visual. Rev Rene. 2012; 13(3):542-51.

13. Leal DR, Mattos GD, Fontana RT. Trabalhador com deficiência física: fragilidades e agravos autorreferidos. Rev Bras Enferm. 2013; 66(1):59-66.

14. Perez VS. Pessoa com deficiência = pessoa incapaz? Um estudo acerca do estereótipo e do papel da pessoa com deficiência nas organizações. Cad EBAPE. 2012; 10(4):883-93.

15. Israel VL, Bertoldi AL. Deficiência físico-motora: interface entre educação especial e repertório funcional. Curitiba: InterSaberes; 2012.

16. Mazzotta MJS, D'Antino MEF. Social Inclusion of People with Disabilities and Special Needs: culture, education and leisure. Saúde Soc. 2011; 20(2):377-89.

17. Pereira R, Osborne R, Pereira A, Cabral SI. The importance of high performance sports in social inclusion of blind people: a study centered on Benjamin Constant Institute - Brazil. Motricidade. 2013; 9(2):94-105.

18. Cárdenas AIG, Cuartas LAH, Bermeo DMC. La rehabilitación para población en condición de discapacidad: participación del educador físico en equipos interdisciplinarios. Des-encuentros. 2011; 9: 28-42.

19. Cardoso VD. A reabilitação de pessoas com deficiência através do desporto adaptado. Rev Bras Ciênc Esporte. 2011; 33(2):529-39. 
20. Rossi P, Munster MA. Natação e Crianças com Deficiência Física: Uma Avaliação do Autoconceito. J Braz Soc Adapted Motor Activity. 2012; 13(2):3842.

21. Ribeiro RKC. Orientação e mobilidade da pessoa com cegueira adquirida: os benefícios do meio aquático como facilitador da aprendizagem. Rev Benjamin Constant. [Internet] 2013 [citado 2014 nov 13]; 19:56. Disponível em: http://www.ibc. gov.br $/$ ? catid $=4 \&$ itemid $=10360$
22. Maia ACB, Ribeiro PRM. Desfazendo mitos para minimizar o preconceito sobre a sexualidade de pessoas com deficiências. Rev Bras Educ Espec. 2010; 16(2):159-76. 